\title{
VEGETAL BURGERS OF CASHEW FIBER AND TEXTURIZED SOY PROTEIN ${ }^{1}$
}

\author{
JANICE RIBEIRO LIMA ${ }^{2}$, DEBORAH DOS SANTOS GARRUTI ${ }^{3}$, \\ GUSTAVO ADOLFO SAAVEDRA PINTO ${ }^{4}$, HILTON CÉSAR RODRIGUES MAGALHÃES 5 , \\ TEREZINHA FEITOSA MACHADO 6
}

\begin{abstract}
This study evaluated the use of cashew fiber in combination with textured soybean protein for the preparation of vegetable burger. Two treatments were studied to reduce fiber size (mechanical pressing with or without enzymatic maceration) and its impact on physical chemical characteristics, sensory acceptance and stability of burgers stored at $-18^{\circ} \mathrm{C}$ for 180 days. Both burger formulations had high moisture and carbohydrate contents and low lipid contents. Enzymatic fiber maceration resulted in harder products with lower moisture content. During storage, reduction in $\mathrm{pH}$ and ascorbic acid and increase in acidity values were observed, with no tendencies for color values. Throughout the storage period, burgers were within microbiological standards of the Brazilian legislation for human consumption and average sensory acceptance was within acceptance zone. It was concluded that the inclusion of enzymatic maceration in the fiber treatment process has no advantages and that burgers elaborated with cashew fiber and textured soybean protein can be consumed up to six months of frozen storage.
\end{abstract}

Index terms: sensory acceptance, proximate composition, microbiological quality, by-product, shelf life.

\section{HAMBÚRGUERES VEGETAIS DE FIBRA DE CAJU E PROTEÍNA TEXTURIZADA DE SOJA}

\begin{abstract}
RESUMO - Neste trabalho, avaliou-se a utilização da fibra de caju em associação à proteína texturizada de soja para elaboração de hambúrguer vegetal. Foram estudados dois tratamentos para a redução do tamanho da fibra (prensagem mecânica associada ou não à maceração enzimática) e seu impacto nas caraterísticas físico-químicas, aceitação sensorial e estabilidade dos hambúrgueres armazenados a $-18^{\circ} \mathrm{C}$, por 180 dias. As duas formulações dos hambúrgueres apresentaram alto teor de umidade e carboidratos, e baixo teor de lipídeos. A maceração enzimática da fibra resultou em produtos com menor umidade e mais duros. Durante o armazenamento dos hambúrgueres, observaram-se redução de $\mathrm{pH}$ e de ácido ascórbico, e aumento de acidez, não tendo sido observadas tendências para os parâmetros de cor. Os hambúrgueres estiveram dentro dos padrões microbiológicos da legislação brasileira para o consumo humano, e as médias de aceitação sensorial, dentro da zona de aceitação durante todo o período de armazenamento. Conclui-se que, a inclusão de maceração enzimática ao processo de tratamento da fibra não apresenta vantagens e que os hambúrgueres obtidos de fibra de caju e proteína texturizada de soja podem ser consumidos até seis meses de armazenamento congelado.
\end{abstract}

Termos para indexação: aceitação sensorial, composição centesimal, qualidade microbiológica, subproduto, vida de prateleira.

\footnotetext{
${ }^{1}$ (Paper 285-15). Received on February 15, 2015. Accepted August 22, 2016.

${ }^{2}$ Food Engineer, D.Sc. in Food Technology, researcher at Embrapa Agroindústria Tropical, Fortaleza-CE. E-mail: janice.lima@embrapa.br ${ }^{3}$ Food Engineer, D.Sc. in Food Science, researcher at Embrapa Agroindústria Tropical, Fortaleza-CE. E-mail: deborah.garruti@embrapa.br ${ }^{4}$ Chemist, D.Sc. in Biochemical Processes, researcher at Embrapa Agroindústria Tropical, Fortaleza-CE. E-mail: gustavo.saavedra@ cnpat.embrapa.br

${ }^{5}$ Pharmacist-biochemist, analyst at Embrapa Agroindústria Tropical, Fortaleza-CE. E-mail: hilton.magalhaes@embrapa.br ${ }^{6}$ Food Engineer, D.Sc. in Biochemistry, researcher at Embrapa Agroindústria Tropical, Fortaleza-CE. Email: terezinha.feitosa@ embrapa.br
} 


\section{INTRODUCTION}

From products derived from cashew apple, juice is the one presenting the largest market and its extraction generates a residue called bagasse or cashew fiber, which represents 20 to $40 \%$ of the cashew apple weight (ROCHA et al., 2014; ALBUQUERQUE et al., BIASOTO et al., 2015, FONTELES et al., 2016). Cashew fiber is traditionally directed to animal feed (SIQUEIRA, BRITO, 2013) or even used as a substrate for the production of co-products such as ethanol and xylitol (ROCHA et al., 2014; ALBUQUERQUE et al., 2015; COSTA et al., 2015).

The use of cashew fiber in human feeding through its incorporation in different foods has been reported by several authors, since it presents dietary fiber content around $12 \%$ of the wet weight, corresponding to $60 \%$ of the dry weight (PINHO et al., 2011). One of the uses of cashew fiber is in meat products, and it has been reported that up to $10 \%$ of beef substitution by cashew fiber in the elaboration of burgers did not cause significant sensorial changes in the product (SIQUEIRA et al., 2002; PINHO et al., 2011). Guedes-Oliveira et al. (2016) have reported the substitution of up to $90 \%$ of fat from chicken parts by cashew fiber without alterations in sensorial attributes. The elaboration of burgers exclusively based on cashew fiber has also been reported (LIMA, 2008); however, the sensorial acceptance of the product was not very good (6 on a 9-point scale), and the size of fibers was one of the main judges' complaints. In addition, burger made only with cashew fiber had low protein content (5.7\%).

Thus, the aim of this study was to evaluate the use of textured soybean protein in association with cashew fiber in the elaboration of vegetable burger in order to obtain higher protein content and acceptability. Two treatments to reduce fiber size (mechanical pressing associated or not with enzymatic maceration) were studied, as well as their impact on the physicochemical characteristics and sensorial acceptance of burgers obtained and their stability in frozen storage for 180 days.

\section{MATERIAL AND METHODS}

\section{Material}

Cashew fiber came from a juice processing industry located in the region of Fortaleza, Ceará. Medium-sized and light textured soybean protein (PTS) was obtained in the local market and was hydrated using PTS and water proportion of 1: $3(\mathrm{~m}$ $/ \mathrm{m})$. The other ingredients of the formulation were also purchased in the local market.

\section{Cashew fiber processing}

Two treatments for cashew fiber processing were tested. In the first one, fiber was processed in a worm screw-type expeller press (Incomap 300, Fortaleza, Brazil) five times to reduce size, acidity and residual cashew taste. At each press, water was added at a ratio of $1: 1(\mathrm{w} / \mathrm{w})$. In the second treatment, fiber was processed in an expeller press as previously described twice and then macerated in a reactor (New Brunswick Bioflo 310, New Jersey, USA) using 3 L of water, $700 \mu \mathrm{L}$ of Celluclast (Novozymes) and $700 \mu \mathrm{L}$ of Viscozyme (Novozymes) for each $\mathrm{kg}$ of fiber, and incubated for $3 \mathrm{~h}$ at $30^{\circ} \mathrm{C}$ and $300 \mathrm{rpm}$ of shaking. After maceration, excess water was removed by pressing the fiber into sieves.

\section{Elaboration of burgers}

For the elaboration of burgers ( 2 treatments with 3 replicates), pressed cashew fiber or macerated and pressed cashew fiber $(27.0 \%)$, textured soybean protein $(27.0 \%)$, tomato $(16.3 \% \%)$, onion $(5.5 \%)$, sweet pepper $(3.1 \%)$, garlic $(0.9 \%)$, washed and chopped into pieces of approximately $1 \mathrm{~cm}$; powder pepper $(0.1 \%)$, dehydrated parsley $(0.2 \%)$, salt $(1.2 \%)$, corn oil $(1.0 \%)$, wheat flour $(8.0 \%)$ and water $(9.7 \%)$ were used. Materials were mixed and cooked until a homogeneous mass was formed, which was shaped into burger form with individual weight of $80 \mathrm{~g}$. Burgers were packed in polyethylene plastic bags and stored frozen $\left(-18^{\circ} \mathrm{C}\right)$ for stability testing.

\section{Proximate composition of burgers}

For the characterization of burgers, moisture, ash, total lipids, proteins and total carbohydrates (by difference) were determined in triplicate (IAL, 2008). The total energy value was also calculated using the conversion factors of $4 \mathrm{kcal} / \mathrm{g}$ for carbohydrates and proteins and $9 \mathrm{kcal} / \mathrm{g}$ for lipids (ANVISA, 2003a).

The results were evaluated by analysis of variance and means were compared by the Tukey test $(\alpha=0.05)$ using the SAS for Windows software (SAS, 2009).

\section{period \\ Stability evaluation during the storage}

The stability of burgers was followed for 180 days with analyses performed every 40 days. At each time, analyses of $\mathrm{pH}$, acidity, ascorbic acid (IAL, 2008), color and microbiology were performed in triplicate. The texture profile was evaluated in 
quintuplicate and the sensorial acceptance by 48 judges.

The color of samples was analyzed using colorimeter (Chroma Meter CR-400, Konica Minolta Sensing Inc., Osaka, Japan) and the CIELab System, which provides the Cartesian coordinates in a threedimensional space, where $\mathrm{L} *$ is the $\mathrm{y}$-axis and quantifies luminosity, ranging from 0 (black) to 100 (white); $\mathrm{a}^{*}$ positions color on the $\mathrm{x}$ axis, ranging from green (values from -60 to 0 ) to red (values 0 to 60$)$ and $b *$ positions color on the $\mathrm{z}$ axis, ranging from blue (values from -60 to 0 ) to yellow (values from 0 to 60 ).

For the texture profile analysis (TPA), burger samples were thawed and stored at $24^{\circ} \mathrm{C}$ for $2 \mathrm{~h}$ to stabilize temperature. $\mathrm{P} / 75$ probe $(75 \mathrm{~mm}$ diameter compression plate) was used, with speed of $5 \mathrm{~mm}$ / s, compression of $5 \mathrm{~mm}$ of the burger height and time between the two compressions of $5 \mathrm{~s}$. Hardness (maximum force required in the first compression of the sample in g), cohesiveness (ratio between the positive area of the curve during the second and the first compression, dimensionless), elasticity (ratio between the time of the second cycle and the first cycle, dimensionless) and adhesiveness parameters (negative area of the force after the first compression, in gs) were evaluated.

Sensory acceptance test (MEILGAARD et al., 2006) was carried out with 48 judges, who were asked to indicate how much they liked burgers using a 9-point structured hedonic scale, ranging from 1 (I disliked very much) to 9 (I liked very much). Judges were also asked about their purchase intention if they found the product for sale, using a 5-point structured scale ranging from 1 (I certainly would not buy) to 5 (I certainly would buy). For the tests, burgers were prepared as for domestic consumption, in nonstick skillet with the addition of $10 \mathrm{~mL}$ corn oil for $5 \mathrm{~min}$ alternating the cooking sides. Samples were served on white disposable plates, coded with random three-digit numbers and presented in a monadic and balanced manner to minimize the effect of sample positioning. A glass of water was offered between samples to eliminate residual taste in the mouth. The protocols of sensory tests were previously approved by the Ethics Research Committee of the State University of Ceará (Protocol no. 147,279).

Microbiological quality was followed by analyses of thermotolerant coliforms, Staphylococcus aureus and Salmonella sp. according to recommendations of the Compendium of Methods for Microbiological Analysis of Foods (DOWNES, ITO, 2001).

The results of stability determinations were evaluated by means of regression analysis using the SAS for Windows software (SAS, 2009).

\section{RESULTS AND DISCUSSION}

\section{Proximate composition and sensory acceptance of burgers}

Burgers elaborated with cashew fiber and PTS were characterized as products of high moisture and carbohydrate and low lipid content (Table 1), and burger elaborated with pressed and macerated fiber presented lower moisture content compared to burger elaborated with only pressed fiber, reflecting higher levels of the other components. When values were compared on a dry basis, only the lipid content showed differences between samples, and burger with pressed and macerated fiber had higher value, which indicates that fiber maceration facilitates fat absorption and / or retention in the burger. However, burgers elaborated with pressed and macerated fiber still had very low lipid content $(1.01 \%$ on wet basis and $3.37 \%$ on dry basis). In a previous study (LIMA, 2008), it was observed that burgers elaborated only with cashew fiber had moisture content of $49.5 \%$, that is, much lower than values obtained in the present study, which was expected, since PTS has the property to absorb water. Thus, for comparison of burger added of cashew fiber (LIMA, 2008) with burger added of cashew fiber and PTS, the composition values were transformed into dry basis. It was observed that the incorporation of PTS into the burger formulation resulted in increase in protein (from $11 \%$ to approximately 19\%) and reduction in lipid contents (from 16\% to approximately $3 \%$ ).

The total energy values were low for both burger formulations (Table 1), and those made with pressed fiber presented lower value compared to those elaborated with pressed and macerated fiber. Considering a burger portion of $80 \mathrm{~g}$ and a recommended intake of $2000 \mathrm{kcal}$ per day (ANVISA, 2003b), burger added of pressed fiber presented 81.4 $\mathrm{kcal}$ and burger added of pressed and macerated fiber presented $92.8 \mathrm{kcal}$, which corresponds to only 4.0 and $4.6 \%$ of the recommended daily calories, respectively. Pinho et al. (2011) studied the elaboration of low-fat burgers using partial replacement of beef by cashew fiber and obtained formulation with $15 \%$ of fiber, which presented 86 $\mathrm{kcal}$ per portion of $80 \mathrm{~g}$, that is, a value similar to that found in this study.

The physicochemical composition and total energy values found for burgers elaborated with cashew fiber and PTS indicate its use for people with calorie restriction, especially if we consider 
that the conventional burger made only with beef has around $170 \mathrm{Kcal}$ per portion of $80 \mathrm{~g}$ (TACO, 2011). In addition, the sensory acceptance of both burgers was above 7.0 on a 9-point scale, corresponding to the hedonic term "I liked".

\section{Stability during storage}

A significant $\mathrm{pH}$ reduction and acidity increase $(\mathrm{p}<0.05)$ (Table 2) was observed during the storage period at $-18^{\circ} \mathrm{C}$ for 180 days for both burger formulations. Neves et al. (2015) studied the refrigerated storage of Brazilian fruit pulps from the Amazon region at $15^{\circ} \mathrm{C}$ for 12 days and did not observe changes in acidity. However, it is known that freezing leads to cell disruption due to the volume change of water transformed into ice, the spatial distribution of ice in the system and the size of ice crystals (PACIULLI et al., 2015). In the present study, cell lysis caused by freezing, especially of burger components that were added chopped to the formulation (tomato and sweet pepper), may have caused greater exposure of acids and caused increase in acidity and reduction in $\mathrm{pH}$.

A significant reduction $(\mathrm{p}<0.01)$ in ascorbic acid content was also observed (Table 2) during frozen storage. Ascorbic acid is an important cashew component found in the pseudo-fruit at levels varying from 140 to $250 \mathrm{mg} / 100 \mathrm{~g}$ (NEVES et al., 2015). The loss of ascorbic acid in foods can be either chemically (non-enzymatic oxidation) or through enzymatic processes, as there are enzymes that resist the processing stages (thermo-resistant) (PHILLIPS et al., 2016), in addition, freezing is not enough to block all enzymatic reactions (MAZZEO et al., 2015). Ascorbic acid is unstable and oxidizable to dehydroascorbic acid, which can still be absorbed by the human body and used as vitamin $\mathrm{C}$; however, it undergoes irreversible oxidation into 2,3-diketogulonic acid, which has no vitamin activity. The presence of oxygen, metal ions and breakdown of the cell structure may favor this process and reduce the ascorbic acid content of foods (LOPEZ-SANCHEZ et al, 2015; PHILLIPS et al., 2016). However, at the end of 180 days of storage, about $53 \%$ of the initial ascorbic acid content remained in both burger samples.

Changes in $\mathrm{pH}$ and acidity of food may also be due to microbial development; however, this was not detected considering the group of microorganisms evaluated. During the monitored period of 180 days, there was absence of Salmonella sp. in $25 \mathrm{~g}$, maximum of $5 \times 10^{2} \mathrm{MPN} / \mathrm{g}$ fecal coliforms $\left(45^{\circ} \mathrm{C}\right)$ and maximum of $10^{3} \mathrm{CFU} / \mathrm{g}$ of Staphylococcus coagulase positive, having met the requirements of Brazilian legislation (ANVISA, 2001). Thus, burgers were considered microbiologically safe for consumption for at least six months.

No significant differences ( $p>0.05)$ were observed in the color coordinates of burgers $\left(\mathrm{L}^{*}\right.$ $a^{*} b^{*}$ ) during frozen storage (Table 2).

Burgers elaborated with only pressed cashew fiber presented greater texture changes during frozen storage (Table 3 ). These burgers showed increased hardness and cohesiveness and reduced adhesiveness, while burgers prepared with pressed and macerated fiber presented only increased cohesiveness. These texture changes may be related to sample compaction over time, which is less evident in hamburgers elaborated with pressed and macerated fiber, since maceration makes fibers easier to pack during the initial product molding. This behavior is consistent with the fact that in burgers elaborated with pressed and macerated fiber, hardness and cohesiveness were already higher since the beginning of the storage period.

No changes were observed in the acceptability and purchase intention during frozen storage for both burger formulations (Table 4). Judges reported they liked the burgers (average score of 7.0 on the hedonic scale) and would probably buy them (average score of 3.8 on the purchase intention scale). Using the same scale, Siqueira et al. (2002) also found average score of 7.0 for overall impression of burgers with up to $10 \%$ replacement of beef by cashew fiber. Nevertheless, Pinho et al. (2011) found much lower averages $(\sim 5.0)$ for overall impression of burgers with 7 to $14 \%$ inclusion of residual cashew powder. These authors suggest that the presence of tannins in the cashew residue could be the cause of the low acceptance of burgers, an effect that is reduced in burgers elaborated in our study due to the pressing stages that also promote fiber washing by the inclusion of water in each cycle. 
TABLE 1- Proximate composition and sensory acceptance of burgers elaborated with cashew fiber and textured soybean protein (mean $\pm \mathrm{sd}$ ).

\begin{tabular}{ccc}
\hline Determination & Pressed fiber & Pressed and macerated fiber \\
\hline Moisture (\%) & $73.36^{\mathrm{a}} \pm 0.10$ & $70.04^{\mathrm{b}} \pm 0.12$ \\
Ash (\%) & $2.04^{\mathrm{b}} \pm 0.01$ & $2.21^{\mathrm{a}} \pm 0.03$ \\
Proteins (\%) & $4.87^{\mathrm{b}} \pm 0.36$ & $5.77^{\mathrm{a}} \pm 0.35$ \\
Lipids (\%) & $0.70^{\mathrm{b}} \pm 0.07$ & $1.01^{\mathrm{a}} \pm 0.03$ \\
Carbohydrates (\%) & $19.03^{\mathrm{b}} \pm 0.20$ & $20.97^{\mathrm{a}} \pm 0.31$ \\
Total energy value (kcal/100g) & $101.87^{\mathrm{b}} \pm 0.35$ & $116.01^{\mathrm{a}} \pm 0.49$ \\
Sensory acceptance (9-point scale) & $7.6^{\mathrm{a}} \pm 1.2$ & $7.3^{\mathrm{a}} \pm 1.3$ \\
\hline
\end{tabular}

In each row, averages followed by the same letters are not significantly different (Tukey, $\alpha=0.05$ ).

TABLE 2- Linear regression of the physicochemical characteristics of burgers elaborated with cashew fiber and textured soybean protein during frozen storage.

\begin{tabular}{ccccccc}
\hline \multirow{2}{*}{ Time (days) } & $\begin{array}{c}\text { Acidity } \\
(\% \text { citric acid) }\end{array}$ & $\mathrm{pH}$ & Ascorbic acid $(\mathrm{mg} / 100 \mathrm{~g})$ & $\mathrm{L}^{*}$ & $\mathrm{a}^{*}$ & $\mathrm{~b}^{*}$ \\
\cline { 2 - 7 } & \multicolumn{5}{c}{ Pressed fiber } \\
\hline 5 & 0.18 & 6.10 & 33.96 & 51.9 & 3.7 & 17.0 \\
47 & 0.18 & 6.23 & 26.69 & 54.8 & 4.4 & 18.1 \\
89 & 0.29 & 6.13 & 17.32 & 44.6 & 3.0 & 11.1 \\
131 & 0.22 & 5.20 & 18.11 & 54.3 & 4.0 & 16.3 \\
180 & 0.26 & 5.75 & 18.10 & 51.1 & 4.1 & 16.0 \\
$\mathrm{p}$ (linear) & 0.01 & 0.02 & $<0.01$ & 0.78 & 0.68 & 0.41 \\
$\mathrm{r}^{2}$ (linear) & 0.41 & 0.38 & 0.74 & 0.01 & 0.02 & 0.04 \\
\hline & & \multicolumn{5}{c}{} \\
\hline 5 & 0.18 & 6.17 & 33.92 & 42.2 & 5.0 & 14.3 \\
47 & 0.18 & 6.10 & 35.55 & 51.4 & 5.1 & 17.0 \\
89 & 0.26 & 5.85 & 25.91 & 43.8 & 3.1 & 12.4 \\
131 & 0.22 & 5.10 & 18.10 & 51.5 & 4.8 & 17.4 \\
180 & 0.26 & 5.75 & 18.13 & 46.2 & 4.8 & 15.2 \\
$\mathrm{p}$ (linear) & $<0.01$ & $<0.01$ & $<0.01$ & 0.27 & 0.61 & 0.59 \\
$\mathrm{r}^{2}$ (linear) & 0.61 & 0.43 & 0.86 & 0.08 & 0.02 & 0.03 \\
\hline
\end{tabular}

TABLE 3-Linear regression of the texture of burgers elaborated with cashew fiber and textured soybean protein during frozen storage.

\begin{tabular}{ccccccccc}
\hline \multirow{2}{*}{$\begin{array}{c}\text { Time } \\
(\text { days })\end{array}$} & \multicolumn{4}{c}{ Pardness Adhesiveness } & \multicolumn{3}{c}{ Pressed and macerated fiber } \\
\hline & $(\mathrm{g})$ & $(\mathrm{gs})$ & \multicolumn{3}{c}{ Elasticity Cohesiveness } & $\begin{array}{c}\text { Hardness } \\
(\mathrm{g})\end{array}$ & $\begin{array}{c}\text { Adhesiveness } \\
(\mathrm{gs})\end{array}$ & Elasticity Cohesiveness \\
\hline 5 & 8469.3 & -536.2 & 0.789 & 0.357 & 11476.8 & -545.0 & 0.799 & 0.586 \\
47 & 10106.4 & -407.6 & 0.842 & 0.349 & 10983.6 & -399.9 & 0.912 & 0.552 \\
89 & 12253.4 & -210.0 & 0.828 & 0.565 & 16036.0 & -511.3 & 0.829 & 0.645 \\
131 & 12935.0 & -225.1 & 0.829 & 0.596 & 21828.3 & -1056.7 & 0.872 & 0.790 \\
180 & 12356.7 & -187.5 & 0.784 & 0.591 & 13967.3 & -188.4 & 0.837 & 0.678 \\
$\mathrm{p}$ (linear) & $<0.01$ & $<0.01$ & 0.79 & $<0.01$ & 0.20 & 0.36 & 0.84 & $<0.01$ \\
$\mathrm{r}^{2}$ (linear) & 0.50 & 0.50 & 0.01 & 0.62 & 0.22 & 0.04 & 0.01 & 0.55 \\
\hline
\end{tabular}


TABLE 4 - Linear regression of sensory acceptance and purchase intention of burgers elaborated with cashew fiber and textured soybean protein during frozen storage.

\begin{tabular}{ccccc}
\hline & \multicolumn{2}{c}{ Pressed fiber } & \multicolumn{2}{c}{ Pressed and macerated fiber } \\
\cline { 2 - 5 } Time (days) & Overall acceptance & Purchase Intention & Overall acceptance & Purchase Intention \\
& 7.6 & 3.9 & 7.3 & 3.9 \\
\hline 5 & 6.8 & 3.6 & 6.6 & 3.6 \\
87 & 7.2 & 3.9 & 7.2 & 4.0 \\
89 & 7.0 & 3.8 & 6.6 & 3.5 \\
131 & 7.2 & 4.0 & 7.0 & 3.7 \\
180 & 0.40 & 0.55 & 0.43 & 0.35 \\
$\mathrm{p}$ (linear) & 0.01 & 0.01 & 0.01 & 0.01 \\
$\mathrm{r}^{2}$ (linear) & & & & \\
\hline
\end{tabular}

\section{CONCLUSIONS}

Enzymatic maceration leads to the formation of harder burgers with lower moisture content; however, it does not influence in their sensory acceptance; then, due to the higher process cost, fiber maceration is not recommended.

Burgers elaborated with cashew fiber and textured soybean protein can be consumed for up to six months if stored under freezing.

\section{REFERENCES}

ALBUQUERQUE, T.L.; GOMES S.D.L.; MARQUES Jr., J.E.; SILVA Jr., I.J; ROCHA, M.V.P. Xylitol production from cashew apple bagasse by Kluyveromyces marxianus CCA510. Catalysis Today, London, v.255, p.33-40, 2015.

ANVISA. Resolução RDC $\mathrm{n}^{0} 12$, de 2 de janeiro de 2001. Regulamento técnico sobre os padrões microbiológicos para alimentos. Disponível em: <http://portal.anvisa.gov.br/wps/wcm/conne ct/9cbab600417aa4088799e722d1e56fc9/anexos res0012_02_01_2001.pdf?MOD=AJPERES $>$. Acesso em: 4 set. 2015.

ANVISA. Resolução RDC $n^{\circ} 359$, de 23 de dezembro de 2003b. Regulamento técnico de porções de alimentos embalados para fins de rotulagem nutricional. Disponível em: $<$ http://portal.anvisa.gov.br/wps/wcm/connect/ d12c9e804745947f9bf0df3fbc4c6735/RDC 359. pdf?MOD=AJPERES $>$. Acesso em: 27 jul. 2015.
ANVISA. Resolução RDC $n^{\circ} 360$, de 23 de dezembro de 2003a. Regulamento técnico sobre rotulagem nutricional de alimentos embalados. Disponível em: < http://portal.anvisa.gov.br/wps/ wcm/connect/1c2998004bc50d62a671ffbc0f9d5b29/ RDC N 360 DE 23 DE DEZEMBRO DE 2003. pdf?MOD=AJPERES $>$. Acesso em: 3 maio 2016.

BIASOTO, A.C.T.; SAMPAIO, K.L.; MARQUES, E.J.N.; SILVA, M.A.A.P. Dynamics of the loss and emergence of volatile compounds during the concentration of cashew apple juice (Anacardium occidentale L.) and the impact on juice sensory quality. Food Research International, London, v.69, p.224-234, 2015.

COSTA, J.A.; MARQUES Jr., J.E.; GONÇALVES, L.R.B.; ROCHA, M.V.P. Enhanced enzymatic hydrolysis and ethanol production from cashew apple bagasse pretreated with alkaline hydrogen peroxide. Bioresource Technology, London, v.179, p.249-259, 2015.

DOWNES, F.P.; ITO, H. Compendium of methods for the microbiological examination of food. $4^{\text {th }}$ ed. Washington: American Public Health Association, 2001 .

FONTELES, T.V.; LEITE, A.K.F.; SILVA, A.R.A.; CARNEIRO, A.P.G.; MIGUEL, E.C.; CAVADA, B.S.; FERNANDES, F.A.N.; RODRIGUES, S. Ultrasound processing to enhance drying of cashew apple bagasse puree: Influence on antioxidant properties and in vitro bioaccessibility of bioactive compounds. Ultrasonics Sonochemistry, London, v.31, p.237-249, 2016. 
GUEDES-OLIVEIRA, J.M.; SALGADO, R.L.; COSTA-LIMA, B.R.C.; GUEDES-OLIVEIRA, J.; CONTE-JUNIOR, C.A. Washed cashew apple fiber (Anacardium occidentale L.) as fat replacer in chicken patties. LWT - Food Science and Technology, Zurich, v.71, 268-273, 2016.

IAL - Instituto Adolfo Lutz. Normas analíticas do Instituto Adolfo Lutz: métodos físico-químicos para análise de alimentos. São Paulo: IAL, 2008. 1020p.

LIMA, J.R. Caracterização físico-química e sensorial de hambúrguer vegetal elaborado a base de caju. Ciência e Agrotecnologia, Lavras, v.32, n.1, p.191195, 2008.

LOPEZ-SANCHEZ, P.; VOS, R.C.H.; JONKER, H.H.; MUMM, R.; HALL, R.D.; BIALEK, L.; LEENMAN, R.; STRASSBURG, K.; VREEKEN, R.; HANKEMEIER, T.; SCHUMM, S.; DUYNHOVEN, J. Comprehensive metabolomics to evaluate the impact of industrial processing on the phytochemical composition of vegetable purees. Food Chemistry, London, v.168, p.348-355, 2015.

MAZZEO, T.; PACIULLI, M.; CHIAVAROA, E.; VISCONTI, A.; FOGLIANO, V.; GANINO, T.; PELLEGRINI, N. Impact of the industrial freezing process on selected vegetables -Part II. Colour and bioactive compounds. Food Research International, London, v.75, p.89-97, 2015.

MEILGAARD, M.; CIVILLE, G. V.; CARR, B. T. Sensory evaluation techniques. $4^{\text {th }}$ ed. New York: CRC Press, 2006.

NEVES, L.C.; TOSIN, J.M.; BENEDETTE, R.M.; CISNEROS-ZEVALLOS, L. Post-harvest nutraceutical behaviour during ripening and senescence of 8 highly perishable fruit species from the Northern Brazilian Amazon region. Food Chemistry, London, v.174, p.188-196, 2015.

PACIULLI, M.; GANINO, T; PELLEGRINI, N.; RINALDI, M.; ZAUPA, M.; FABBRI, A.; CHIAVARO, E. Impact of the industrial freezing process on selected vegetables. Part I- Structure, texture and antioxidant capacity. Food Research International, London, v.74, p.329-337, 2015.
PHILLIPS, K.M.; COUNCIL-TROCHE, M.; MCGINTY, R.C.; RASOR, A.S.; TARRAGOTRANI, M.T. Stability of vitamin $C$ in fruit and vegetable homogenates stored at different temperatures. Journal of Food Composition and Analysis, London, v.45, p.147-162, 2016.

PINHO, L.X.; AFONSO, M.R.A.; CARIOCA, J.O.B.; COSTA, J.M.C.; RAMOS, A.M. The use of cashew apple residue as source of fiber in low fat hamburgers. Ciência e Tecnologia de Alimentos, Campinas, v.31, n.4, p.941-945, 2011.

ROCHA, M.V.P.; RODRIGUES, T.H.S.; ALBUQUERQUE, T.L.; GONÇALVES, L.R.B.; MACEDO, G.R. Evaluation of dilute acid pretreatment on cashew apple bagasse for etanol and xylitol production. Chemical Engineering Journal, London, v.243, p.234-243, 2014.

SAS. Statistical analysis system user's guide. Cary: SAS Institute, 2009.

SIQUEIRA, A.M.A.; BRITO, E.S. Aproveitamento do bagaço do caju para alimentação humana e utilização em outras indústrias de alimentos. In: ARAÚJO, J.P.P. Agronegócio caju: práticas e inovações. Brasília, DF: Embrapa, 2013. pte 5. cap. 3, p. 349-361.

SIQUEIRA, S.P.; RETONDO, J.C.; MARCELLINI, P.S.; FARIA, J.F. Substituição parcial da carne bovina por bagaço de caju na elaboração de hamburgueres. In: CONGRESSO BRASILEIRO DE CIÊNCIA E TECNOLOGIA DE ALIMENTOS, 18., 2002, Porto Alegre. Anais... Porto Alegre: SBCTA, 2002. CD ROM.

TACO - Tabela Brasileira de Composição de Alimentos. Campinas: NEPA,Unicamp 2011. 161p. Disponível em: <http://www.unicamp.br/nepa/ taco/contar/taco 4 edicao ampliada e revisada. pdf? arquivo $=$ taco 4 versao ampliada e revisada. pdf $>$. Acesso em: 20 jul. 2015. 